\title{
EFFECTS OF THE GRADATION MAPS OBTAINED BY TWO DIFFERENT METHODS ON THE LAND CONSOLIDATION PROJECTS IN TURKEYS
}

\author{
${ }^{1}$ Mevlüt UYAN, ${ }^{2}$ Tayfun ÇAY \\ ${ }^{1}$ Selcuk University, Directorate of Construction \& Technical Works, Campus, Selcuklu, Konya, TURKEY \\ ${ }^{2}$ Selcuk University, Department of Geomatic Engineering, Campus, Selcuklu, Konya, TURKEY \\ 1muyan@selcuk.edu.tr, 2tayfuncay@selcuk.edu.tr
}

(Geliş/Received: 04.07.2017; Kabul/Accepted in Revised Form: 09.08.2017)

\begin{abstract}
Land consolidation (LC) can be defined as rearranging the rural area in line with the needs of the society and individuals according to the needs of the developing agricultural technology, and taking all necessary measures to enable agricultural enterprises to work more efficiently. Reallocation quantity depends on the agricultural land valuation. In Turkey, LC projects are performed by different two legal institutions and these institutions use different methods for the production of gradation maps. The purpose of this study was to determine and evaluate effects of different gradation maps obtained by the two different methods for two different legal institutions for the same project area. According to finding in this study, the results of both methods are seen as close to each other. First, in the study area, there were 1216 cadastral parcels. The number of the parcels after application of Law 3083 decreased to 614 in the 35 new blocks. Furthermore, the number of parcels decreased to 749 in the 35 new blocks after the application of Law 5403. Models were compared in terms of parcel sizes. In the reallocation according to the two methods, differences according to the average squares are below that specified in the regulations error limit. This case demonstrates the applicability of both methods. So, law 3083 "Agrarian Reform Act for Land Arrangements in Irrigation Areas" and law 5403 "Soil Conservation and Land Use" should be combined under the same framework. New regulations for this case will relax practitioners.
\end{abstract}

Key Words: Agricultural land gradation, Land consolidation, Land reallocation.

\section{Türkiye'de İki Farklı Yöntemle Elde Edilmiş Derecelendirme Haritalarının Arazi Toplulaştırma Projelerine Etkisi}

ÖZ: Arazi toplulaştırması (AT), gelişen tarımsal teknolojinin ihtiyaçlarına göre toplumun ve bireylerin ihtiyaçları doğrultusunda kırsal alanın yeniden düzenlenmesi ve tarımsal işletmelerin daha verimli çalışması için gerekli önlemlerin alınması olarak tanımlanabilir. Yeniden dağıtım miktarları tarımsal alanların derecelendirilmesine bağlıdır. Türkiye'de AT projeleri iki farklı yasal kurum tarafından gerçekleştirilmektedir ve bu kurumlar derecelendirme haritalarının oluşturulmasında farklı yöntemler kullanmaktadır. Bu çalışmanın amacı, aynı proje alanında iki farklı yasal kurum için iki farklı yöntemle elde edilen derecelendirme haritalarının etkilerini belirlemek ve değerlendirmektir. Bu çalışmadaki bulgulara göre, her iki yöntemin sonuçları birbirine yakın olarak görülmektedir. İlk olarak, çalışma alanında, 1216 kadastral parsel vardı. 3083 sayılı Kanunun uygulanmasından sonra parsellerin sayısı 35 yeni blokta 614'e düşmüştür. Ayrıca, 5403 sayılı Kanunun uygulanmasından sonra 35 yeni blokta parsel sayısı 749'a düşmüştür. Modeller parsel büyüklükleri açısından karşılaştırılmıştır. İki yönteme göre yeniden dağıtımda, ortalama kareler yöntemine göre farklar yönetmelik hata sınırında belirtilenin altındadır. Bu durum, her iki yöntemin uygulanabilirliğini göstermektedir. Bu nedenle, 3083 sayılı "Sulama Alanlarında Arazi Düzenlemeleri için Tarım Reformu Yasası" ve 5403 sayılı "Toprak Koruma 
ve Arazi Kullanımı Kanunu" aynı çerçeve altında birleştirilmelidir. Bu durum için yapılacak yeni düzenlemeler uygulayıcıları rahatlatacaktır.

Anahtar Kelimeler: Tarımsal arazi derecelendirme, Arazi toplulaştırma, Yeniden dağıtım.

\section{INTRODUCTION}

The agricultural sector is the primary source of economic activity for rural areas in Turkey. Therefore, the agricultural sector is the driving force behind rural development efforts as well as being an important element of national development (Cay and Uyan, 2013). The majority of Turkish people are employed in agriculture (Bayrakcı and Koçar, 2012), which has a share, according to 2007 data, of about $8.9 \%$ of GDP, and approximately $23.2 \%$ of the total population are engaged in this important sector (TUIK, 2008).

In Turkey, 8.5 million ha can be irrigated economically. However, only 4.8 million ha are being irrigated at present. The average farm size was 10 ha in 1950, 6.8 ha in 1980, 5.9 ha in 1990 and 6.1 ha in 2001; the numbers of farms in the same years were 2.2 million, 3.5 million, 3.9 million and 3.02 million respectively. The average parcel number per landholding is 4.08 , according to the results of the General Agricultural Census in 2001 (Cay et al., 2010).

Land degradation is a serious problem for sustainable agriculture in Turkey, as in most places in the world, and can cause permanent damage. It is also a global problem with serious economic and environmental impacts (Cay and Uyan, 2013; Niroula and Thapa, 2005; Prazan and Dumbrovsky, 2011). Turkey loses $\$ 10$ billion annually because of fragmented agricultural fields. Land consolidation (LC) is the most favorable land management approach for solving land degradation and has been applied in many countries around the world (Demetriou et al., 2012).

LC is rearranging land and taking precautions to ensure more fruitful working of land areas according to the development of agricultural technology. LC is essential for ensuring the economic viability of rural areas, facilitating environmental management, or rationalizing urban growth. LC in rural areas not only aims at combining fragmented parcels but also better management of all related areas such as agricultural, technical, social and cultural areas to improve standards of land ownership (Cay and Uyan, 2013; Cay et al., 2010; Pasakarnis and Maliene, 2010). In many countries, it is a major tool in the development of rural areas lagging behind or with major adjustment problems (Van Huylenbroeck et al., 1996).

LC can be described as the main measure in an effort to eliminate land fragmentation and improve the prevailing defective land tenure structure, which is primarily characterized by: a small holding size, intense land fragmentation, mixed land tenures (i.e. land held undivided form and dual or multiple ownerships), lack of farm roads and irregularly shaped plots (Kizilsu, 2002).

In Turkey, while only 450,000 ha of fragmented agricultural land were consolidated from 1961 to 2002, 5 million ha of fragmented agricultural land were consolidated between 2002 and 2013. The aim is to consolidate 5 million ha of fragmented agricultural land between 2013 and 2017.

LC is an indispensable application in sustainable agriculture and an extremely effective method for increasing land process efficiency and supporting rural development (Blaikie and Sadeque, 2000; Niroula and Thapa, 2007; Sklenicka, 2006). Moreover, LC is an extremely important method for many different applications such as environmental protection (Martinez et al., 2013; Uhling, 1989; Zhang and Zhao, 2013), urban development (Gonzalez et al., 2004; Liu et al., 2013), fighting erosion in rural areas (Chartin et al., 2013; Mihara, 1996; Yang et al., 2010), developing rural areas and managing other social and economic problems (Crecente et al., 2002; Coelho et al., 1996; Ivkovic et al., 2010; Kirmikil and Arici, 2013; Lerman and Cimpoies, 2006; Quadflieg, 1997; Sklenicka et al., 2009).

LC projects consist of various steps. Land reallocation is the most important stage of LC studies and a tool which rearranges proprietary rights. Within this stage, agricultural land valuation is one of the most difficult, critical and time-consuming stages, since a high number of criteria are considered. For 
land valuation, the expert-surveyor, with a delegation of the local commission and all persons who know the land, goes on the terrain to observe the parcels and to classify them (Derlich, 2002). The purpose of this stage is to ensure equivalent that the new parcels will be given to the landowners after LC with their previous parcels. It is extremely important for the success of land consolidation.

LC projects in Turkey are performed by different legal institutions (General Directorate of Agricultural Reform and Provincial Special Administration) operating under two legal arrangements. These institutions use different methods for the production of agricultural land valuation and gradation maps. In this case, two different agricultural land valuation maps are produced for the same area. Agricultural land valuation leads to some important differences, since LC projects are done by different legal institutions and legal regulations. In this study, reallocation process was performed using agricultural land valuation maps obtained by the two different methods for two different legal institutions for the same project area. The results of the two legal institutions were compared with each other.

\section{MATERIAL AND METHOD}

\section{Study Area}

The town of Kozluca in the Burdur Province, Turkey, was chosen as the study area. It is situated 45 $\mathrm{km}$ in Burdur (Figure 1). The project area is a plain of 470 ha used for LC in Kozluca. There are 385 landowners in the LC area, who own 1216 cadastral parcels, of which $276(22.70 \%)$ are shared parcels (Figure 2). The average parcel size per landowner is $3848 \mathrm{~m}^{2}$. The cultivated products are mostly wheat and barley. The average height above sea level is about $1110 \mathrm{~m}$. The average annual rainfall was $472 \mathrm{~mm}$ between 2000 and 2010. The town of Kozluca is located in the part of the country with the least rainfall, where the continental climate conditions prevail with summers that are hot and arid while winters are cold and snowy.

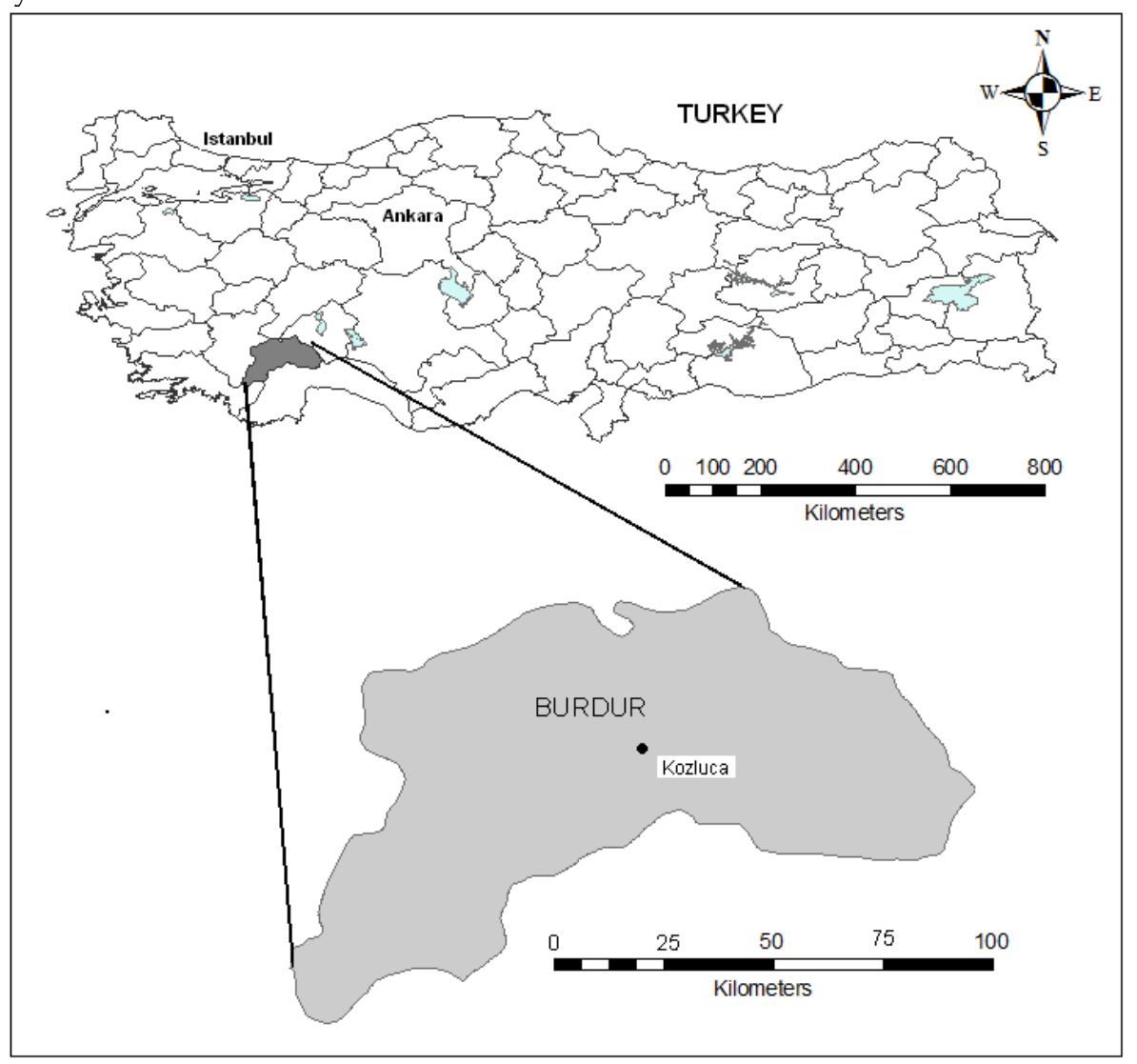

Figure 1. Geographical position of Kozluca town. 


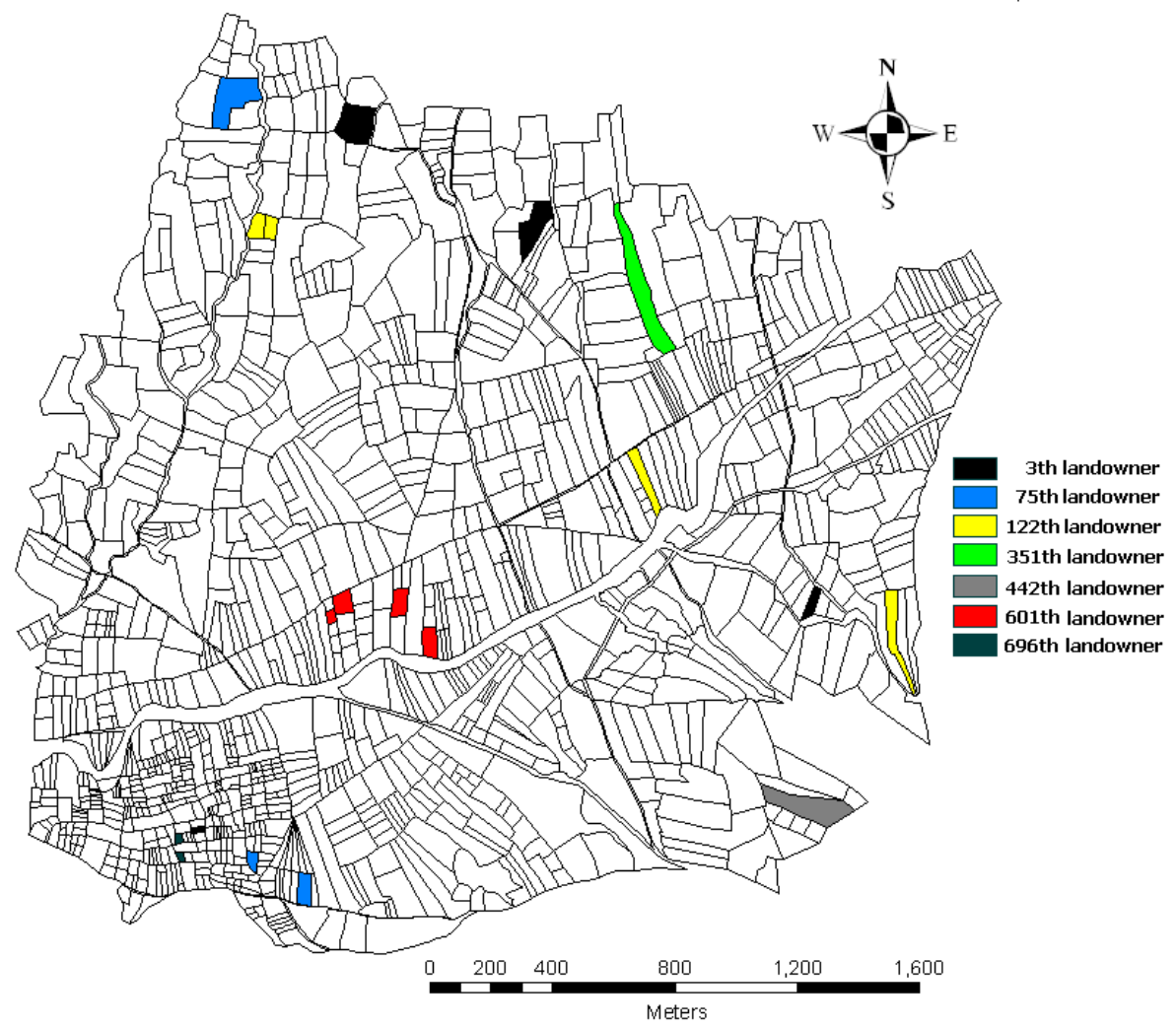

Figure 2. Cadastral situation of Kozluca town.

\section{Methodology}

Agricultural land classification and gradation mapping of the land consolidation projects are performed by two different law and legal institutions. An LC study in the application areas of agrarian reform is performed by the Directorate General of Agrarian Reform (TRGM), according to Land Reform regarding rearrangement of land in irrigated areas (Law no. 3083, date: 1984), and in other areas by Special Provincial Administration, according to Soil Conservation and Land Use Law (Law no. 5403, date: 2005).

\section{Agricultural land valuation according to Law no. 3083}

The land reform of 1984, no. 3083, regarding the rearrangement of land in irrigated areas, also includes land reform stylistically. This law also predicts determined land norm (amount of land which can provide living space for a farmer's family) for the publicising of big landowners' lands and provision of land for farmers who do not have land (Ulger and Cay, 2012).

The agricultural land valuation method in LC studies uses Parcel Unit Value (PUV), according to Law No. 3083. Soil Indices (SI) and Current Value Indices (CVI) are determined for all parcels in project areas. PUV is obtained as follows:

$$
\mathrm{PUV}=(\mathrm{SI}+\mathrm{CVI})) / 2
$$

Where SI is obtained as follows: 
Where A is the group of soil profile, B is the soil structure, $\mathrm{C}$ is the slope of the land, $\mathrm{X}$ is the other qualifications such as salinity, $\mathrm{pH}$.

CVI for per agricultural land are determined taking into account some features such as the yield of the land, the possible range of products, the soil property, the status of irrigation, the distance to road and irrigation channels and the distance to the village and market by members of the local commission. Determined highest SI and CVI values are scored as 100 points and others are ranked according to this value proportionally.

When the parcels have more than one SI and CVI, the PUV is more than one. Thus, by computing the weighted mean values of these indices, a weighted mean value of the parcels is obtained. After the highest weighted mean value of the parcels is accepted as first rank, the parcels in the study area are ranked. If there are approximately the same weighted mean values of the parcels in the study, their mean values are obtained and this is called rank mean point. By rating rank mean points with themselves, the equivalency of degrees is provided (Demir et al., 2002). The CVI values are associated with generated SI maps, numerically, and gradation maps created.

\section{Agricultural land valuation according to Law no. 5403}

In Turkey, legal regulations concerning land conservation have only been in place since 2005. LC studies were performed in accordance with the 1979 "Land Consolidation Statute". At different times, various items were added to this statute. In 2005, "Soil Conservation and Land Use Law", no. 5403, was implemented.

The objective of this law is rearrangement in accordance with the sustainable development of agricultural areas without losing properties.

Law, generally, includes use of land property right, determining soil and land existence, classification of agricultural areas and determining land parcel sizes, protection of land and land use, use of agriculture land, land consolidation and distribution matters.

The agricultural land valuation method in LC studies uses parcel indices (PI) according to Law No. 5403. Parcels in the LC project area are ranked for computed transformation values. The parcel indices (PI) of each parcel were calculated using the grading maps, as follows:

$$
\mathrm{PI}=0.70 \times \mathrm{SI}+\mathrm{P}+\mathrm{L}
$$

Where SI is calculated as in section 2.1 and then marked as 100 points; P refers to the productivity of the soil, marked as 10 points; and $\mathrm{L}$ is the location index of the parcel and marked as 20 points. According to this law, agricultural land was graded 10, whereas grade 8-10 land was not evaluated and grade 1-7 land was arranged in one group (Cay et al., 2010; Demir et al., 2002), as shown in Table 1. Gradation maps for the LC project area are created according to PI values.

Table 1. Grade of agricultural lands.

\begin{tabular}{|cc|}
\hline Grade & PI \\
\hline 1 & $91-100$ \\
2 & $81-90$ \\
3 & $71-80$ \\
4 & $61-70$ \\
5 & $51-60$ \\
6 & $41-50$ \\
7 & $31-40$ \\
8 & $21-30$ \\
9 & $11-20$ \\
10 & $0-10$ \\
\hline
\end{tabular}




\section{RESULT AND DISCUSSION}

In Turkey, LC projects generally have four basic stages (Cay et. al., 2010):

-Preliminary study

-Planning

- Project making

-Application

Land value classification is determined in the planning stage. The grading commission consists of six persons: president (project manager-agricultural engineer), two agricultural engineers from related institutions, mayor or village headman and two persons who are elected from among landowners in the project area. The project manager is the key figure in the land valuation and is responsible for overall progress. He is the link between landowners and the administration, and should develop procedures for establishing land values.

Preparation of a valuation scale on soil characteristics or current prices can be very complicated and the choices should be carefully assessed. The particular circumstances of the project area may influence the selection of the valuation approach to use according to Law no. 3083 or 5403 .

Impact on the valuation of the SI is 50\% in Law no. 3083 and $70 \%$ in Law no. 5043, according to formula (1) and (3). If soil samples are not taken frequently enough for SI values obtained from chemical analysis, very different SI values can be obtained. In this case, land value classification maps can be calculated incorrectly.

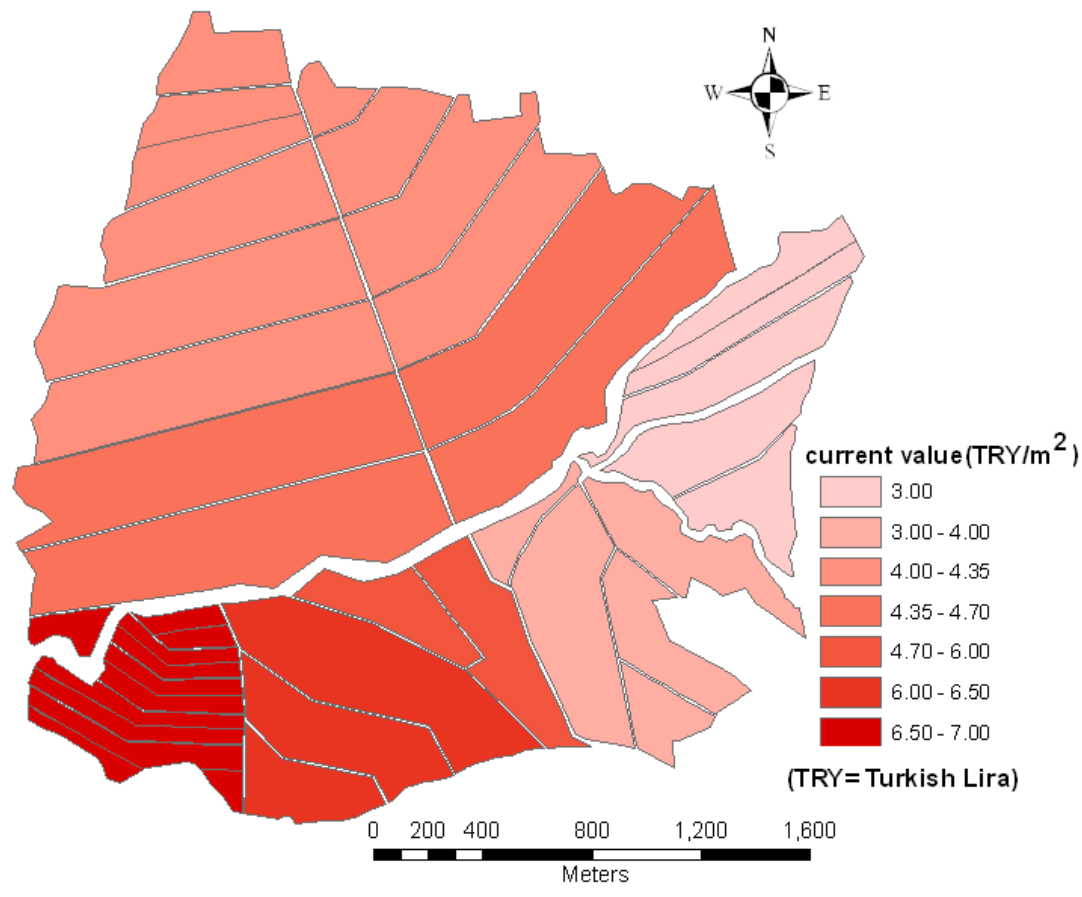

Figure 3. Current value map of Kozluca town.

Firstly, according to Law no. 3083, land value classification is made in the study area. SI values were obtained from the grading commission's studies. Direct negotiations were realized between seller and buyer by the grading commission to establish CVI values. Some official valuations may be used, for example, based on soil surveys and other factors which indicate relative differences in the value of agricultural parcels. Such official values may not be based on current values, but may provide useful information for the establishment of current values. The aim is to agree on current values which are acceptable to both sellers and buyers. A determined current value map by grading commission is shown in Figure 3. PUV was obtained according to formula (1). 
Secondly, according to Law no. 5403, land value classification is made in the study area. Again, the same SI values were obtained from the grading commission's studies as Law no. 3083. Otherwise, P and $\mathrm{L}$ values were determined by the grading commission. PI was obtained according to formula (2).

Prepared land valuation maps by the grading commission according to both Law no. 3083 and Law no. 5403 are shown in Figure 4a and Figure 4b respectively.

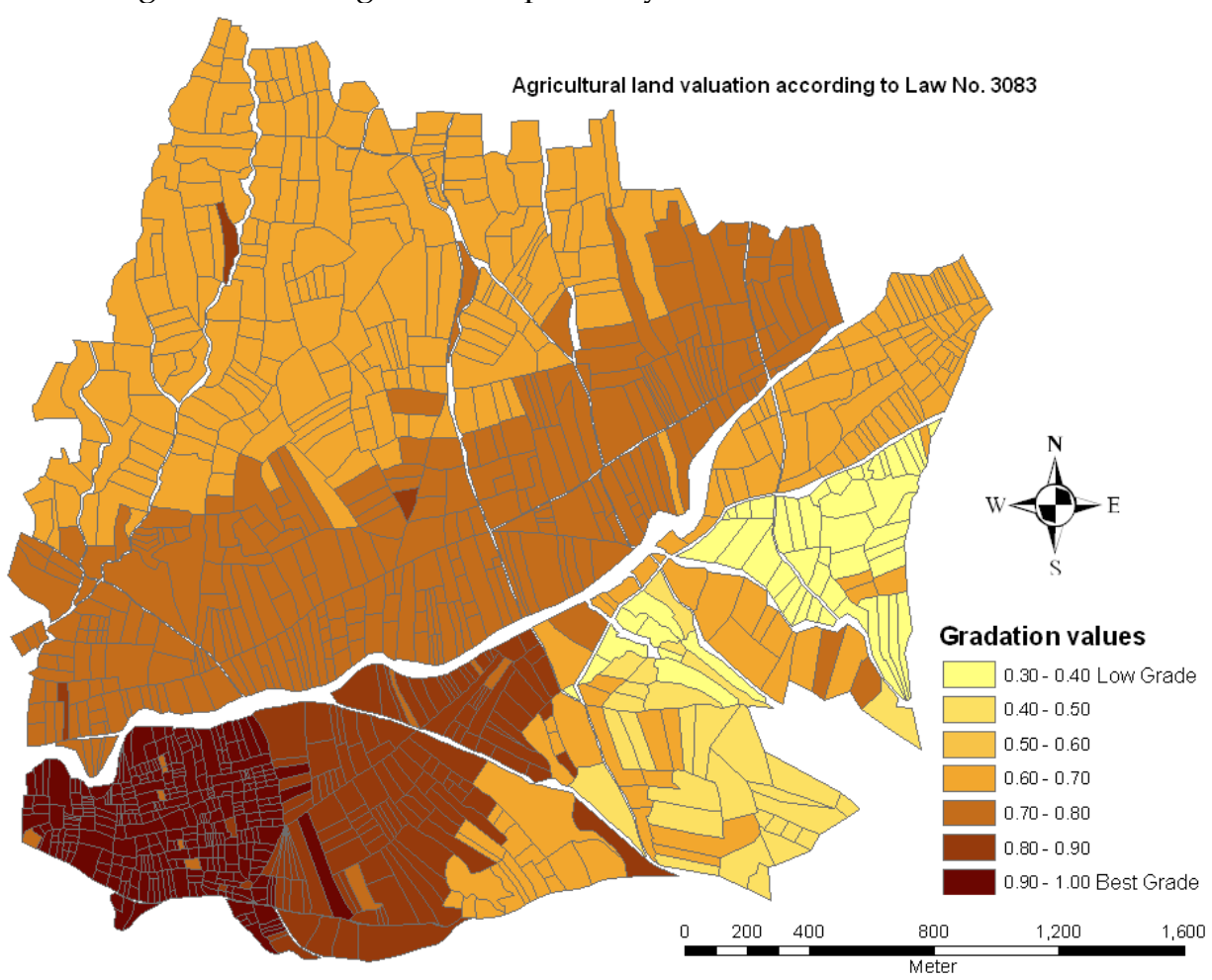

Figure 4a. Land valuation maps according to Law no. 3083.

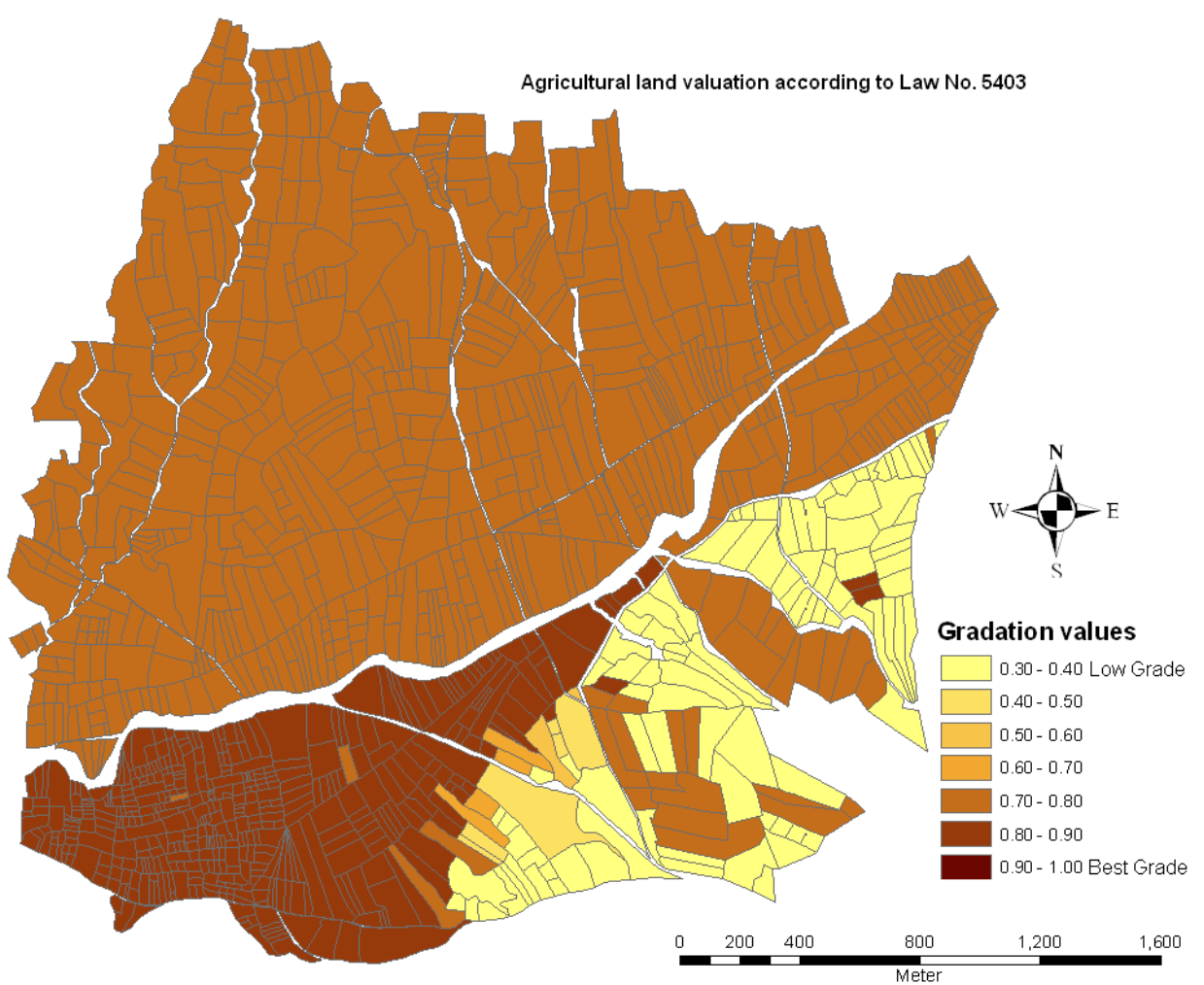

Figure $4 \mathrm{~b}$. Land valuation maps according to Law no. 5403. 
Table 2. Determined reallocation square values for some parcels with PUV and PI.

\begin{tabular}{|c|c|c|c|c|c|c|c|}
\hline $\begin{array}{c}\text { Parcel } \\
\text { No }\end{array}$ & $\begin{array}{c}\text { Pre-LC } \\
\text { Square }\left(\mathrm{m}^{2}\right)\end{array}$ & SI & CVI & PUV & PI & $\begin{array}{c}\text { Post-LC } \\
\text { New Square }\left(\mathrm{m}^{2}\right) \\
\text { Law No. } 3083\end{array}$ & $\begin{array}{c}\text { Post-LC } \\
\text { New Square }\left(\mathrm{m}^{2}\right) \\
\text { Law No. } 5403\end{array}$ \\
\hline $1 / 2122$ & 15800 & 0.78 & 0.67 & 0.725 & 0.78 & 14785 & 14553 \\
\hline $1 / 2239$ & 18638 & 0.78 & 0.61 & 0.695 & 0.78 & 13843 & 14995 \\
\hline $1 / 2242$ & 8125 & 0.78 & 0.61 & 0.695 & 0.78 & 7603 & 7755 \\
\hline $1 / 2244$ & 7713 & 0.78 & 0.67 & 0.725 & 0.78 & 6120 & 7362 \\
\hline $1 / 2299$ & 4150 & 0.84 & 0.86 & 0.85 & 0.78 & 4372 & 642 \\
\hline $1 / 2310$ & 3375 & 0.78 & 0.67 & 0.725 & 0.78 & 3158 & 3222 \\
\hline $1 / 2349$ & 7050 & 0.84 & 1 & 0.92 & 0.78 & 6858 & 6729 \\
\hline $1 / 2370$ & 2500 & 0.84 & 0.67 & 0.755 & 0.84 & 1169 & 1285 \\
\hline $1 / 2371$ & 7000 & 0.84 & 1 & 0.92 & 0.84 & 2770 & 2227 \\
\hline $1 / 2529$ & 1675 & 0.84 & 0.93 & 0.885 & 0.39 & 1913 & 1599 \\
\hline $1 / 2530$ & 463 & 0.84 & 1 & 0.92 & 0.84 & 450 & 442 \\
\hline $1 / 2571$ & 625 & 0.84 & 1 & 0.92 & 0.84 & 584 & 1285 \\
\hline $1 / 2590$ & 3425 & 0.84 & 0.93 & 0.885 & 0.84 & 154 & 3520 \\
\hline $1 / 2591$ & 3625 & 0.84 & 1 & 0.92 & 0.84 & 3650 & 3460 \\
\hline $1 / 2592$ & 3013 & 0.84 & 0.93 & 0.885 & 0.78 & 2819 & 2876 \\
\hline $1 / 2622$ & 16400 & 0.84 & 1 & 0.92 & 0.78 & 15953 & 10667 \\
\hline $1 / 2630$ & 1100 & 0.84 & 0.93 & 0.885 & 0.84 & 1310 & 1050 \\
\hline $1 / 2633$ & 1700 & 0.84 & 1 & 0.92 & 0.39 & 1653 & 1747 \\
\hline $1 / 2642$ & 850 & 0.84 & 1 & 0.92 & 0.84 & 1009 & 812 \\
\hline $1 / 2643$ & 750 & 0.84 & 1 & 0.92 & 0.84 & 729 & 715 \\
\hline $1 / 2644$ & 1500 & 0.84 & 1 & 0.92 & 0.84 & 1459 & 1432 \\
\hline $1 / 2645$ & 800 & 0.84 & 1 & 0.92 & 0.78 & 748 & 763 \\
\hline $1 / 2646$ & 850 & 0.84 & 1 & 0.92 & 0.78 & 504 & 406 \\
\hline $1 / 2647$ & 850 & 0.84 & 1 & 0.92 & 0.78 & 1209 & 874 \\
\hline $1 / 2648$ & 1750 & 0.84 & 0.67 & 0.755 & 0.84 & 1637 & 1799 \\
\hline $1 / 2649$ & 1000 & 0.84 & 1 & 0.92 & 0.84 & 619 & 477 \\
\hline $1 / 2991$ & 5075 & 0.84 & 0.86 & 0.85 & 0.84 & 5567 & 5217 \\
\hline $1 / 3001$ & 11925 & 0.84 & 0.86 & 0.85 & 0.78 & 13083 & 11382 \\
\hline $1 / 3002$ & 550 & 0.84 & 0.86 & 0.85 & 0.84 & 629 & 565 \\
\hline $1 / 3013$ & 5175 & 0.84 & 0.86 & 0.85 & 0.84 & 4474 & 4939 \\
\hline $1 / 3014$ & 6725 & 0.84 & 0.86 & 0.85 & 0.84 & 7378 & 668 \\
\hline $1 / 3033$ & 1225 & 0.78 & 0.67 & 0.725 & 0.84 & 1146 & 1169 \\
\hline $1 / 3034$ & 1225 & 0.78 & 0.67 & 0.725 & 0.84 & 1146 & 1086 \\
\hline $1 / 3039$ & 3613 & 0.78 & 0.67 & 0.725 & 0.78 & 3381 & 3449 \\
\hline $1 / 3055$ & 2625 & 0.78 & 0.67 & 0.725 & 0.78 & 2456 & 2505 \\
\hline $1 / 3073$ & 3688 & 0.78 & 0.67 & 0.725 & 0.78 & 3451 & 3269 \\
\hline $1 / 3168$ & 5200 & 0.78 & 0.61 & 0.695 & 0.78 & 4866 & 4963 \\
\hline $1 / 3169$ & 6450 & 0.78 & 0.61 & 0.695 & 0.78 & 8739 & 6156 \\
\hline $1 / 3774$ & 12700 & 0.78 & 0.67 & 0.725 & 0.78 & 5942 & 6062 \\
\hline $1 / 3787$ & 1700 & 0.78 & 0.67 & 0.725 & 0.78 & 1590 & 1623 \\
\hline $1 / 3794$ & 17700 & 0.78 & 0.67 & 0.725 & 0.78 & 16563 & 16895 \\
\hline $1 / 3795$ & 8200 & 0.78 & 0.67 & 0.725 & 0.78 & 13434 & 7827 \\
\hline $1 / 3975$ & 2517 & 0.78 & 0.43 & 0.605 & 0.84 & 1178 & 1201 \\
\hline $1 / 4017$ & 4200 & 0.78 & 0.43 & 0.605 & 0.78 & 3421 & 3723 \\
\hline
\end{tabular}


With calculated new areas as in Table 2, reallocation stage was completed according to Law no. 3083 and Law no. 5403. First, parcels are placed in the new blocks according to Law no. 3083. Second, parcels are placed in the new blocks according to Law no. 5403. The new parceling plan drawn up is shown in Figure 5. Also, it is compared with locations and area of new parcels belonging to the 3th, 75th, 122th, 351th, 442th, 601th and 696th landowners after land reallocation (Figure 5 and Table 3). After LC, the difference between squares according to Law no.3083 and Law no.5403 is within acceptable limits according to the following formula.

$$
\mathrm{df}=0.00042 \times \mathrm{M} \times \sqrt{\mathrm{F}}
$$

This formula gives acceptable difference between the two squares. Here, df means the error limit in $\mathrm{m} 2$, M means the map scale and $\mathrm{F}$ means the parcel square in $\mathrm{m}^{2}$.

The cadastral situation of these landowners is shown in Figure 2. The results of the Law no. 3083based land reallocation model were compared with the results of the Law no. 5403-based land reallocation model.

First, in the study area, there were 1216 cadastral parcels. The number of the parcels after application of Law no. 3083 decreased to 614 in the 35 new blocks (Figure 5b). Furthermore, the number of parcels decreased to 749 in the 35 new blocks after the application of Law no. 5403 (Figure 5b). Models were compared in terms of parcel sizes (Table 4).

Table 3. Comparison of some landowners' squares

\begin{tabular}{|l|lllll|}
\hline $\begin{array}{c}\text { Landowner } \\
\text { no }\end{array}$ & $\begin{array}{l}\text { Pre-LC } \\
\text { Square }\left(\mathbf{m}^{2}\right)\end{array}$ & $\begin{array}{l}\text { Post-LC } \\
\text { Square }\left(\mathbf{m}^{2}\right)\end{array}$ & $\begin{array}{l}\text { Change } \\
\text { Rate } \\
\text { According to 3083 }\end{array}$ & $\begin{array}{l}\text { Post-LC } \\
\text { Square }\left(\mathbf{m}^{2}\right)\end{array}$ & $\begin{array}{l}\text { Change } \\
\text { rate }\end{array}$ \\
\hline $\mathbf{3}$ & 15182 & 13451 & -11.4 & 13202 & According to 5403 \\
$\mathbf{7 5}$ & 22050 & 22329 & 1.27 & 21046 & -13.04 \\
$\mathbf{1 2 2}$ & 21425 & 17043 & -20.45 & 16133 & -4.55 \\
$\mathbf{3 5 1}$ & 22600 & 21149 & -6.42 & 21572 & -24.7 \\
$\mathbf{4 4 2}$ & 18000 & 19720 & 9.56 & 17179 & -4.55 \\
$\mathbf{6 0 1}$ & 15563 & 14564 & -6.42 & 14855 & -4.56 \\
$\mathbf{6 9 6}$ & 1750 & 1638 & -6.42 & 1799 & -4.55 \\
\hline
\end{tabular}

Table 4. Comparison of parcel sizes.

\begin{tabular}{|l|cc|}
\hline \multicolumn{1}{|c|}{ Parcel size } & Square $\left(\mathbf{m}^{2}\right)$ & Increase rate (\%) \\
\hline $\begin{array}{l}\text { Cadastre parcel size } \\
\text { Parcel size based on the Law } \\
\text { no. } \mathbf{3 0 8 3}\end{array}$ & 3848 & - \\
$\begin{array}{l}\text { Parcel size based on Law no. } \\
\mathbf{5 4 0 3}\end{array}$ & 5151 & 185 \\
\hline
\end{tabular}




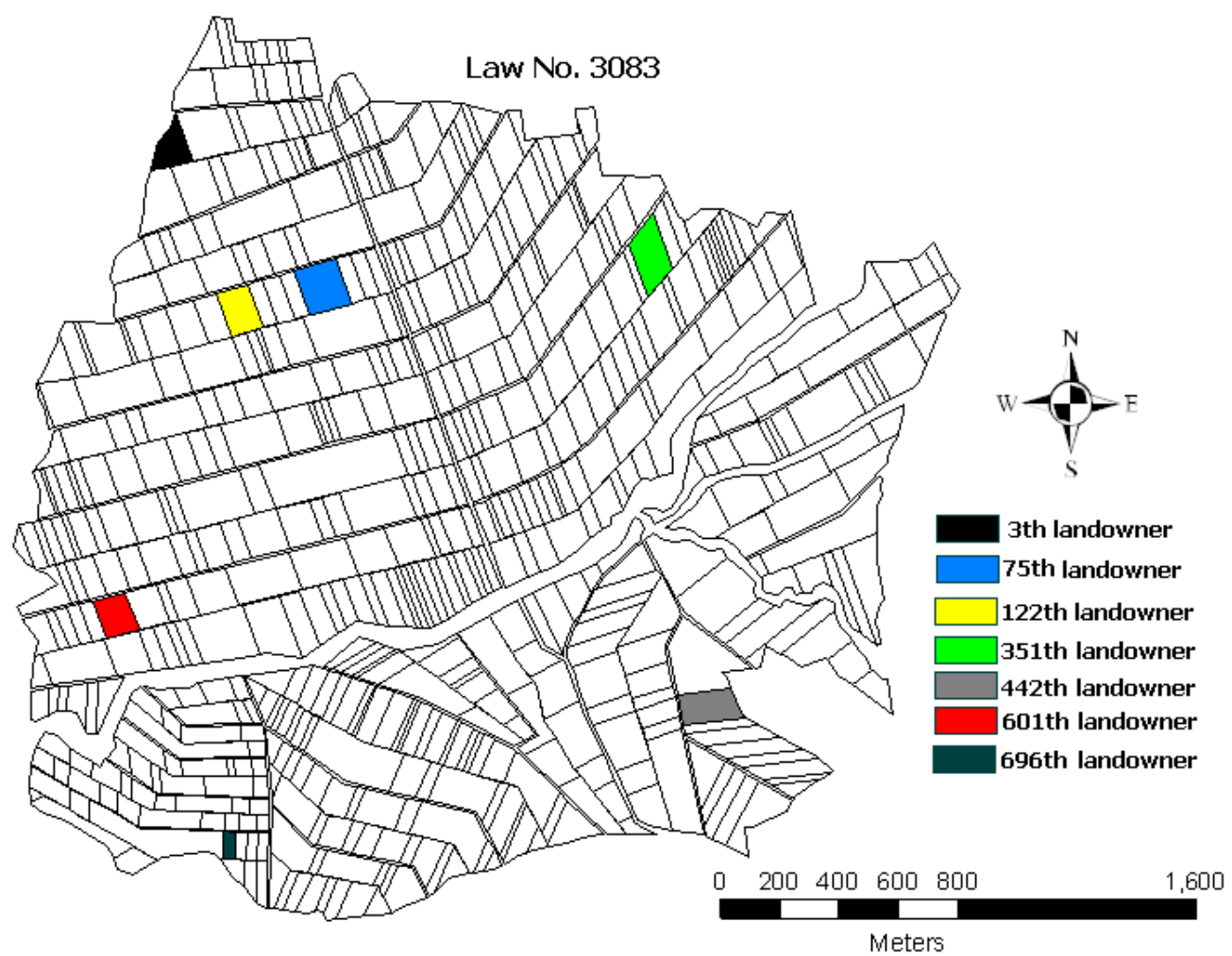

Figure 5a. New parceling plan drawn according to Law no. 3083.

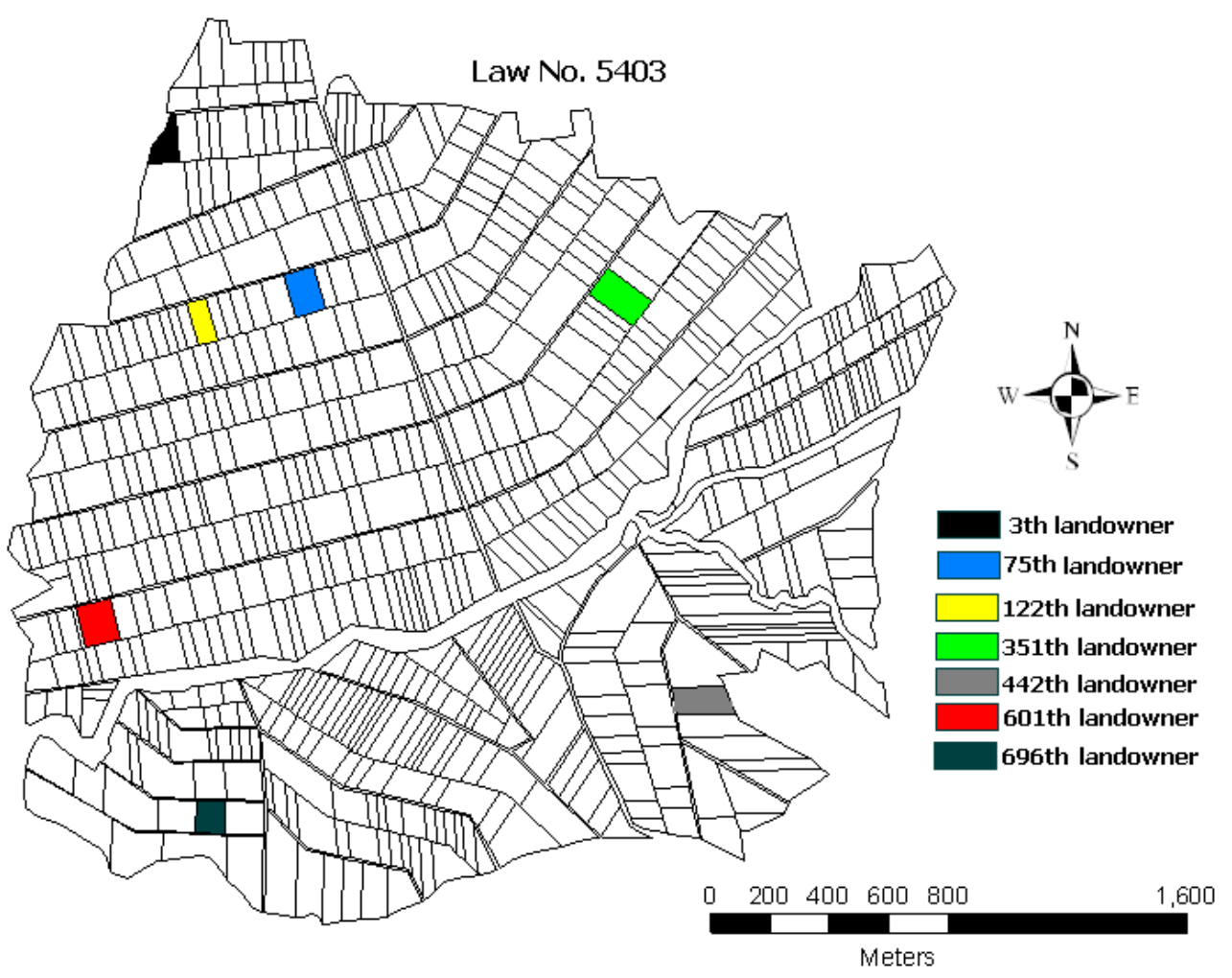

Figure 5b. New parceling plan drawn according to Law no. 5403. 


\section{CONCLUSION}

In rural areas, LC not only aims at combining disorganized land areas, but also at resolving problems in all related areas of agriculture, as well as taking technical, social and cultural precautions to improve landowning standards (Cay and Uyan, 2013). LC projects consist of various steps. Within these stages, agricultural land valuation is important, critical and time-consuming since a high number of criteria are considered. LC projects in Turkey are performed by the Ministry of Food, Agriculture and Livestock (GTHB) operating under two legal arrangements (Law no. 3083 "Agrarian Reform Act for Land Arrangements in Irrigation Areas" and Law no. 5403 "Soil Conservation and Land Use"). These laws use different methods for the production of agricultural land valuation and gradation maps. However, the steps of the application are the same as the general steps.

In terms of project applications, the use of two different laws is negative. According to findings in this and many similar studies, the results of both methods are seen as close to each other. In the reallocation according to the two methods, differences according to the average squares are below that specified in the regulations error limit. This case demonstrates the applicability of both methods. So, no. 3083 "Agrarian Reform Act for Land Arrangements in Irrigation Areas" and no. 5403 "Soil Conservation and Land Use" should be combined under the same framework. The responsible ministry for the projects under the scope of both laws is GTHB. Although the LC project carried out by the responsible ministry for the execution of turkey GTHB in the execution of projects by disparate legislation causes confusion. However, the execution of projects according to different legislations causes the confusion. For this reason, in order to get a standard in LC projects, it is necessary to prepare a common legislation to be used by all institutions and organizations wishing to make LC. In the case of a joint legislation, technical instructions must be prepared in detail. New arrangements will facilitate the control unit's work in case of problems during implementation.

Most of the problems that arise in practice can easily be resolved by changes in legislation. For this reason, it is no doubt that projects will be healthier and faster if a common legislation system is used by the institutions and organizations that carry out the LC project.

\section{REFERENCES}

Bayrakc1, A. G., Koçar, G., 2012, “Utilization of Renewable Energies in Turkey's Agriculture”, Renewable and Sustainable Energy Reviews, Vol. 16(1), pp. 618-633.

Blaikie, P. M., Sadeque, A. Z., 2000, "Policy in the High Himalayas: Environment and Development in the Himalayan Region", ICIMOD, Kathmandu.

Cay, T., Uyan, M., 2013, “Evaluation of Reallocation Criteria in Land Consolidation Studies Using the Analytic Hierarchy Process (AHP)", Land Use Policy, Vol. 30, pp. 541-548.

Cay T., Ayten T., Iscan F., 2010, "Effects of Different Land Reallocation Models on the Success of Land Consolidation Projects: Social and Economic Approaches", Land Use Policy, Vol. 27(2), pp. 262 269.

Chartin, C., Evrard, O., Salvador-Blanes, S., Hinschberger, F., Van Oost, K., Lefevre, I., Daroussin, J., Macaire, J. J., 2013, "Quantifying and Modelling the Impact of Land Consolidation and Field Borders on Soil Redistribution in Agricultural Landscapes (1954-2009)", Catena, Vol. 110, pp. 184-195.

Coelho, J. C., Portela, J., Pinto, P. A., 1996, "A Social Approach to Land Consolidation Schemes - A Portuguese Case Study: The Valenca Project", Land Use Policy, Vol. 13(2), pp. 129-147.

Crecente, R., Alvarez, C., Fra, U., 2002, "Economic, Social and Environmental Impact of Land Consolidation in Galicia", Land Use Policy, Vol. 19(2), pp. 135-147.

Demetriou, D., Stillwell, J., See, L., 2012, “Land Consolidation in Cyprus: Why is an Integrated Planning and Decision Support System Required?", Land Use Policy, Vol. 29(1), pp. 131-142. 
Demir, H., Gür, M., Cagdas, V., 2002, "Land Consolidation, Valuation and Cadastre", FIG XXII International Congress, Washington, USA, 19-26 April 2002.

Derlich, F., 2002 "Land Consolidation: A Key for Sustainable Development - French Experience", FIG XXII International Congress, Washington, USA, 19-26 April 2002.

Gonzalez, X. P., Alvarez, C. J., Crecente, R., 2004, “Evaluation of Land Distributions with Joint Regard to Plot Size and Shape", Agricultural Systems, Vol. 82, pp. 31-43.

Ivkovic, M., Barkovic, D., Bacani, S., 2010, "Land Consolidation and Rural Development", Geodetski List, Vol. 64(4), pp. 297-312.

Kirmikil, M., Arici, I., 2013, "The Role of Land Consolidation in the Development of Rural Areas in Irrigation Areas", Journal of Food Agriculture \& Environment, Vol. 11(2), pp. 1150-1155.

Kizilsu, G., 2002, "Land Consolidation in Rural Areas with Lacis" International Symposium on GIS, Istanbul-Turkey, 23-26 September 2002.

Lerman, Z., Cimpoies, D., 2006, "Land Consolidation as a Factor for Rural Development in Moldova", Europe-Asia Studies, Vol. 58 (3), pp. 439-455.

Liu, Y. S., Yang, R., Li, Y. H., 2013, "Potential of Land Consolidation of Hollowed Villages under Different Urbanization Scenarios in China", Journal of Geographical Sciences, Vol. 23(3), pp. 503512.

Martinez, R., Solla, M., Arias, P., Armesto, J., 2013, “Semi-automatic Land Consolidation Software based on Geographic Information Systems", Computers and Electronics in Agriculture, Vol. 97, pp. 1-5.

Mihara, M., 1996, "Effects of Agricultural Land Consolidation on Erosion Processes in SemiMountainous Paddy Fields of Japan", Journal of Agricultural Engineering Research, Vol. 64 (3), pp. 237-247.

Niroula, G. S., Thapa, G. B., 2007, "Impact of Land Fragmentation on Input Use, Crop Yield and Production Efficiency in the Mountains of Nepal", Land Degradation and Development, Vol. 18, pp. 237-248.

Niroula, G. S., Thapa G. B., 2005, "Impacts and Causes of Land Fragmentation, and Lessons Learned from Land Consolidation in South Asia", Land Use Policy, Vol. 22(4), pp. 358-372.

Pasakarnis, G., Maliene, V., 2010, “Towards Sustainable Rural Development in Central and Eastern Europe: Applying Land Consolidation", Land Use Policy, Vol. 27, pp. 545-549.

Prazan, J., Dumbrovsky, M., 2011, "Soil Conservation Policies: Conditions for Their Effectiveness in the Czech Republic", Land Degradation \& Development, Vol. 22 (1), pp. 124-133.

Quadflieg, F., 1997, "An Economist's View of the Measures Introduced to Accompany the Change in the Agrarian Structure", Berichte Uber Landwirtschaft, Vol. 75, pp. 501-514.

Sklenicka, P., Hladik, J., Strelecek, F., Kottova, B., Lososova, J., Cihal, L., Salek, M., 2009, “Historical, Environmental and Socio-Economic Driving Forces on Land Ownership Fragmentation, the Land Consolidation Effect and the Project Costs", Agricultural Economics-Zemedelska Ekonomika, Vol. 55(12), pp. 571-582.

Sklenicka, P., 2006, "Applying Evaluation Criteria for the Land Consolidation Effect to Three Contrasting Study Areas in the Czech Republic", Land Use Policy, Vol. 23, Issue 4, pp. 502-510.

TUIK, 2008, “Tarım İstatistikleri-Sorularla Resmi İstatistikler Dizisi” 5. TÜİK Matbaası, Ankara.

Uhling, J., 1989, "Land Consolidation Agriculture and Environmental Protection", Berichte Uber Landwirtschaft, Vol. 67, pp. 426-456.

Van Huylenbroeck, G., Coelho, J., Pinto, P.A., 1996, “Evaluation of Land Consolidation Projects (LLCs): a Multidisciplinary Approach", Journal of Rural Studies, Vol. 12 (3), pp. 297-310.

Ulger, N. E., Cay, T., 2012, "An Assessment about Land Consolidation in Turkey", FIG Working Week, Rome, Italy.

Yang, Z.S., Yang, L. F., Zhang, B. S., 2010, “Soil Erosion and Its Basic Characteristics at Karst Rockydesertified Land Consolidation Area: A Case Study at Muzhe Village of Xichou County in Southeast Yunnan, China", Journal of Mountain Science, Vol. 7 (1), pp. 55-72. 
Zhang, Z. F., Zhao, W., 2013, "A Parametric Approach to Assess the Sustainability of Land Consolidation: A Case Study in Shandong Province, North China", Agroecology and Sustainable Food Systems, Vol. 37(4), pp. 444-464. 